\title{
Interanimal memory transfer of a barpress response through brain and liver RNA injections
}

\author{
G. L. HOLT and G. BENTZ \\ Eastern Illinois University, Charleston, Illinois 61920
}

\begin{abstract}
Interanimal memory transfer of a discriminated operant barpress task resulted in a significantly higher frequency of barpresses from recipients of trained-brain and -liver ribonucleic acid (RNA) extracts. Three were trained to criterion on a light-and-tone and three were trained on a dark-and-tone discriminated operant barpress. Two RNA extracts were taken from these six trained donors' livers and brains. One extract from each donor's brain and liver was subjected to ribonuclease (RNase). The 12 brain and liver RNase and 12 brain and liver non-RNasetreated extractions were intraperitoneally injected into separate naive recipients. Those rats receiving "trained" RNA showed significantly $(p<.025)$ greater interanimal memory for task transfer than those animals receiving RNase-treated RNA extracts.
\end{abstract}

Results of several experiments have shown a functional relationship between RNA and the process of learning and memory. With respect to the role of RNA and learning, McConnell, Jacobson, and Kimble (1959) showed that when trained planaria were cut in half transversely and allowed to regenerate, both head and tail parts took significantly less time to relearn an avoidance response task. Later, McConnell, Jacobson, and Humphries (1961) fed two groups of planarians pieces of conditioned and naive planarians. Those ingesting conditioned planarians showed a higher shock avoidance response rate during initial stages than those ingesting naive planarians. These studies suggested that learning may be transferable between organisms and that learning is not specific only to brain tissue. In an attempt to further identify RNA as a transferring agent, Corning and John (1961) added ribonuclease (RNase), a substance that breaks down RNA, as a control. Planarians were trained and then cut in half, and one-half of the subjects were allowed to regenerate. The heads of the flatworms regenerating in RNase demonstrated the same savings in learning as the trained controls, whereas the tails not regenerating in the RNase showed no savings. Concurrently, Hýden (1961) discovered that RNA content was higher in nerve cells than in other types of cells. In addition, he demonstrated that the amount of RNA present in the cells increases as a function of sensory stimulation. Later, Cameron (1961) found that intravenous injections of yeast RNA into arteriosclerotic patients improved learning and memory performance. Brown (1966) showed that a leverpress response rate increased significantly when yeast RNA was injected into recipient rats, whereas rats not treated with RNA showed no increase in response rate. Further, Ison and Taplin (1966) injected reagent grade RNA into rats and found their ability to perform complex learning prob- lems in a Hebbs-Williams maze to be increased compared to rats not treated with RNA.

Four important results of the above experiments have been demonstrated: (1) RNA of any type does enhance learning in human and nonhumans, (2) RNA increases under brain stimulation, (3) RNA is higher in nerve cells than in many other cell types, and (4) RNase is a good control for future RNA memory transfer experiments.

Later, many researchers did show that enhancement of learning and transfer of memory could both be achieved with RNA injections from trained donors (Babich, Jacobson, Bubash, \& Jacobson, 1965; Cook, Davidson, Donis, Griffin, \& Fellows, 1963). Despite several researchers' reporting positive findings, many were unable to show transfer of learning and memory even though they used several different extraction procedures (Byrne, Samuel, Bennett, Rosenzweig, \& Wasserman, 1966), modes of injection, and tasks (Hoffman, Stewart, \& Bhagavan, 1967; Luttges, Johnson, Buck, \& Holland, 1966). Until recently the controversy of whether RNA is a viable site of memory storage has gone unsettled. In historical retrospect, it can be seen that those who obtained RNA transfer of learned tasks were criticized on the basis that what was transferred was not memory but merely an artifact of the facilitatory effects due to increased RNA concentration in the brain from RNA injections. These criticisms, in addition to the many experiments that were unable to show transfer effects due to the two experiments' not being exactly replicated, produced a temporary impasse in research in this area. These findings, however, were interpreted in terms of stress rather than interanimal memory transfer. However, more recently, a series of experiments employing several control methods showed that memory of a discrete task could be transferred from trained donors to 
naive recipients using RNA from brain and liver tissue (Miller \& Holt, 1977). In addition, the dosage of RNA in interanimal memory transfer was found to be important (Holt \& Miller, 1983). Higher dosages of RNA from the discrete task-trained donors produced stronger tasktransfer effects than did lower dosages.

Due to the nature of the task and the RNase controls, the findings could not be criticized on the basis of facilitation. Further, the brain and liver were both found to be storage sites for learned information, and it was found that specific information stored in these tissues could be transferred to other animals. Further, RNA seems to play a significant role in the processes of learning enhancement, as well as memory for discrete tasks, and these processes are not specific only to the brain. A majority of past research has been conducted to test for learning enhancement rather than memory of a specific task. In addition, there has been little control for additional sources of transfer other than RNA, such as DNA and proteins.

The present experiment was designed to determine if the memory of a specific discriminated operant barpress response would transfer from one rat to another through intraperitoneal injections of trained RNA. In addition, the barpress response, which is a relatively complex behavior, was designed to reduce the possibility that the animal exhibits a chance response or that RNA acts simply as a facilitator to learning. Controls such as dialysis, which removes smaller molecules, and RNase, which indicates if any other substance is responsible for the transfer effect, were employed. Of primary concern was that the biochemical and extraction procedures be kept almost identical to a prior series of experiments (Miller \& Holt, 1977).

\section{METHOD}

\section{Subjects}

Six male and female albino rats, weighing approximately $325 \mathrm{~g}$ each, were maintained at $80 \%$ ad-lib weight.

\section{Apparatus}

The apparatus consisted of six standard operant chambers, $27 \times 22.5 \times 19.5 \mathrm{~cm}$. The food cup was $5 \mathrm{~cm}^{2}$ and located $.5 \mathrm{~cm}$ above the chamber floor. The operant bar was subject operated.

\section{Preliminary Training}

Following a deprivation period of 1 week, six rats were trained to press the operant bar and receive a $45-\mathrm{mg}$ Noyes food pellet. Once the rats were bar trained, three rats were trained to a light-and-tone discriminative stimulus and three rats were trained to a dark-and-tone discriminative stimulus. Training was terminated when the rats barpressed under the correct condition at $90 \%-100 \%$ accuracy.

\section{Procedure}

After the training period, trained rats were sacrificed by intraperitoneal injection of $1 \mathrm{cc}$ of nembutal. The whole brain and liver were removed from each rat, and the RNA was extracted using the following procedure. The RNA from each donor was kept separate according to donor and tissue throughout the experiment.

Each tissue was placed in a cold mortar and ground for approximately $10 \mathrm{~min}$ in a mixture of $10 \mathrm{ml}$ of $90 \%$ phenol and $10 \mathrm{ml}$ of isotonic saline. This mixture was then centrifuged at $7,000 \mathrm{rpm}$ for $1 \mathrm{~h}$ and $30 \mathrm{~min}$. The aqueous phase was drawn off to avoid contamination with phenol or the interphase. The aqueous phase was then buffered with $.2 \mathrm{~g}$ of $\mathrm{MgCl}_{2}$, and two volumes of cold ethanol were then added to the mixture and allowed to precipitate for $15 \mathrm{~min}$. The solution was then centrifuged at $7,000 \mathrm{rpm}$ for $30 \mathrm{~min}$, after which the supernatant liquid was poured off. The solution was then washed with ethanol three times to dissolve any remaining phenol in the sample. The remaining ethanol was evaporated, and the RNA was dissolved in $3 \mathrm{ml}$ of isotonic saline. The solution was dialyzed against saline for $24 \mathrm{~h}$. The amount of RNA was then determined by an optical density of $260 \mathrm{MU}$ using spectrophotometric analysis. The RNA from each sample was divided into two portions, yielding two samples of brain RNA and two samples of liver RNA. One portion from each donor, for each tissue, was then treated with RNase and incubated for $12 \mathrm{~h}$ at $37^{\circ} \mathrm{C}$. The other portions, not treated with RNase, were also allowed to incubate for $12 \mathrm{~h}$ at $37^{\circ} \mathrm{C}$. The 24 naive recipient rats were kept at $80 \%$ ad-lib weight and were placed in an inoperative operant chamber prior to the RNA injections. The six liver and six brain RNase-treated extracts were then injected intraperitoneally into naive rats, each one being labeled according to the tissue it received. The six liver and six brain nonRNase-treated extracts were also injected intraperitoneally into naive rats, each one also being labeled according to the tissue it received. All recipient rats were then tested for $20 \mathrm{~min}$ in an operant chamber at 4-, 6-, 8-, and 24-h intervals after injections. The response measured was the first disciminated operant barpress response.

\section{RESULTS}

Table 1 shows the number of rats who barpressed in both the experimental non-RNase group and the control RNase group. Subjects receiving untreated brain and liver RNA showed a $100 \%$ barpress response rate. Rats receiving RNase-treated brain and liver RNA showed a 58\% response rate. A Fisher exact-probability test indicates that the difference was significant at the $\mathrm{p}<.025$ level. Both brain and liver showed equal potential for memory storage and interanimal transfer of the discrimintated operant barpress response.

Table 1

Number of Animals Responding per Group

\begin{tabular}{cccc}
\hline Subject & $\begin{array}{c}\text { Experimental } \\
\text { Group }\end{array}$ & Subject & $\begin{array}{c}\text { Control } \\
\text { Group }\end{array}$ \\
\hline 1 & y & 1 & y \\
2 & y & 2 & y \\
3 & y & 3 & y \\
4 & y & 4 & y \\
5 & y & 5 & n \\
6 & y & 6 & y \\
7 & y & 7 & n \\
8 & y & 8 & n \\
9 & y & 9 & y \\
10 & y & 10 & $\mathrm{n}$ \\
11 & y & 11 & y \\
12 & y & 12 &
\end{tabular}




\section{DISCUSSION}

Past research in interanimal learning and memory transfer has shown that RNA may be responsible for the transfer and storage of memory (Corning \& John, 1961; Holt \& Miller, 1982; McConnell et al., 1959; Miller \& Holt, 1977). Some studies have, however, failed to produce learning and enhancement and memory transfer through RNA injections (Byrne et al., 1966; Gordon, Deanin, Leonhart, \& Gwynn, 1966; Luttges et al., 1966). In the interanimal memory transfer involving sometimes sensitive biochemical processes, the issue of proper RNase controls and exact procedural replication of processes used in research finding successful transfer is of paramount importance.

The purpose of this experiment was to replicate findings of previous research (Miller \& Holt, 1977) and to attempt transfer of a more complex behavior involving a discriminated operant barpress response using biochemical controls. Instead of measuring savings or the ability to learn a specific task, the criterion was the first barpress response after the animal was placed in the operant chamber. Thus, memory transfer, and not learning enhancement, was measured. Additional controls such as dialysis, RNase, and double-blind procedures helped insure that RNA was the transfer agent.

The results of this experiment have added much to the reliabililty of previous findings, in that a positive transfer effect was produced using both brain and liver tissue.

The successful transfer of a more specific behavior poses the question as to potential limits to the complexity of behavior that can be transferred. This research leaves open the possibility that substances other than RNA may also have some role in the transfer of memory. Only through further research is it possible to resolve this highly controversial topic and determine decisively the biochemical basis for learning and memory.

\section{RETERENCES}

Babich, F. R., Jacobson, A. L., Bubabh, S., \& Jacobson, A. Transfer of a response to naive rats by injection of ribonucleic acid from trained rats. Science, 1965, 149, 656-657.

Brown, H. Effect of ribonucleic acid (RNA) on the rate of lever pressing in rats. Psychological Record, 1966, 16, 173-176.
Bymez, W., Samuel, D., Bennett, D., Roseneweio, M., \& Wasormuan, E. Memory transfer. Sclence, 1966, 153, 658-659.

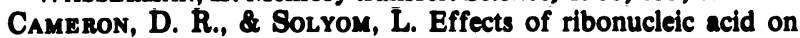
memory. Geriatrics, 1961, 16, 74-81.

Coox, L., Davideon, A., Donis, D., Grifrin, H., \& Fellows, E. Ribonucleic acid: Effects on conditioned behavior in rats. Science, 1963, 140, 268-269.

Cornina, W. C., \& John, E. R. Effects of ribonuclease on retention of conditioned response in regenerated planarians. Science, 1961, 134, 1363-1365.

Gordon, M., Deanin, G., Leonhart, H., \& Gwynn, R. RNA and memory: A negative experiment. American Journal of Psychiatry, 1966, 10, 1174-1178.

Hotrman, R. F., Strewart, C. N., \& Bhagavan, H. N. Failure to transfer a learned response in rats using a brain extract containing RNA. Psychonomic Science, 1967, 9, 151-152.

Holt, G. L., \& MiLler, B. E. Interanimal task transfer as a function of dosage of brain and liver RNA injections. Bulletin of the Psychonomic Society, 1983, 21, 47-50.

HYDEN, H. Satellite cells in the nervous system. Scientfic American, 1961, 205, 62-70.

Ison, J. R., \& TAPLIN, P. Reagent grade yeast RNA injections and rat performance on the Hebbs-Williams maze. Psychonomic Science, 1966, 6, 495-496.

Jacobson, A. L., BABich, F. R., \& Jacobson, R. Differential approach tendencies produced by injection of RNA from trained rats. Science, 1965, 150, 636-637.

Lutraes, M., Johnson, T., Buck, C., Holland, J., \& McGaugh, J. An examination of "transfer of learning" by nucleic acid. Science, 1966, 151, 834-837.

MoConnell, J. V., Jacobson, A. L., \& Kimble, D. P. The effects of regeneration upon retention of conditioned response in planarians. Journal of Comparative and Phystological Psychology, 1959, 52, 1-5.

McConnell, J. V., Jacobson, R., \& Humpheirs, B. M. The effects of ingestion of conditioned planaria on the response level of naive planaria. Worm Runner's Digest, 1961, 3, 41-45.

Miller, B. E., \& Holt, G. L. Memory transfer in rats by infection of brain and liver RNA. Journal of Biological Psychology, $1977,19,4-9$.

(Received for publication November 15, 1982.) 